\title{
BULANIK MANTIK YÖNTEMIYYE KIZILÇAMDA VERİMLİLİĞİN MODELLENMESİ
}

\section{Emre KUZUGÜDENLI*}

Süleyman Demirel Üniversitesi, Yenişarbademli Meslek Yüksekokulu, Ormancllık Bölümü, Isparta, Türkiye

\begin{tabular}{l}
\hline Anahtar Kelimeler \\
\hline Yetişme Ortamı, \\
Bonitet Endeksi, \\
Dalaman(Muğla), \\
Bulanık Mantık, \\
Kızılçam (Pinus brutia Ten).
\end{tabular}

Öz

Bu çalışma, orman ekolojisi alanında bulanık mantık yönteminin kullanılabilirliğini araştırmak ve neticesinde araştırma sahasına benzer ekolojik koşullara sahip yörelerde yapılacak ağaçlandırma çalışmalarında başarıyı artırmak amacıyla Ege bölgesi, Dalaman(Muğla) yöresinde gerçekleştirilmiştir. Bu amaçla araştırma sahası olan Dalaman yöresinde 40 adet örnek alan belirlenmiştir. Bağımlı değişken olan bonitet endeksini belirlemek amacıyla her örnek alanda üst boy ve yaş ölçümleri yapılmıștır. Araştırmanın bağımsız değişkenleri için de örnek alanlarda enlem, boylam, yükselti, bakı, eğim, arazi formu, yamaç konumu, sıcaklık, yağış ve büyük toprak grubu değişkenleri belirlenmiştir. Yapılan istatistiksel analizler sonucunda bulanık mantık modellemesinin tahmin gücü $\left(R^{2}=0,6845\right)$ regresyon modellemesine $\left(\mathrm{R}^{2}=0,4589\right)$ oranla çok daha yüksek çıkmıştır. Çalışma sonucunda bulanık mantık yönteminin orman ekolojisi çalışmalarında alternatif bir metot olarak kullanılma potansiyelinin olduğu görülmüştür.

\section{MODELING PRODUCTIVITY OF BRUTIAN PINE BY FUZZY LOGIC METHOD}

\begin{tabular}{l}
\hline Keywords \\
\hline Site, \\
Site index, \\
Dalaman(Mugla), \\
Fuzzy Logic, \\
Brutian pine(Pinus brutia \\
Ten.).
\end{tabular}

Alıntı / Cite

Kuzugüdenli, E., (2018). Bulanık Mantık Yöntemiyle Kızılçamda Verimliliğin Modellenmesi, Journal of Engineering Sciences and Design, 6(3), 426-434.

Yazar Kimliği / Author ID (ORCID Number)

E. Kuzugüdenli, 0000-0003-2513-6070

\begin{abstract}
This study has been carried out in the Dalaman region (Mugla) in order to increase the success of afforestation brutian pine forests in the Dalaman and similar regions as well as the availability of the fuzzy logic method in forest ecology studies. For this purpose, 40 sample plots were determined in the Dalaman region, which is the research area. In order to determine the site index, which is the dependent variable, the height and age of each sample plots were measured. For the independent variables of the study, variables such as latitude, longitude, elevation, aspect, slope, land form, slope position, temperature, precipitation and soil group were measured in the sample plots. As a result of statistical analysis, the estimation power of the fuzzy logic model $\left(\mathrm{R}^{2}=0.6845\right)$ was much higher than the regression model $\left(\mathrm{R}^{2}=\right.$ $0.4589)$. As a result of the study, it is seen that the fuzzy logic method has potential to be used as an alternative method in forest ecology studies.
\end{abstract}

\begin{tabular}{|l|l|}
\hline \multicolumn{2}{|l}{ Makale Süreci / Article Process } \\
\hline Başvuru Tarihi / Submission Date & 09.04 .2018 \\
Revizyon Tarihi / Revision Date & 25.05 .2018 \\
Kabul Tarihi / Accepted Date & 26.07 .2018 \\
Yayım Tarihi / Published Date & 21.09 .2018 \\
\hline
\end{tabular}

\section{Giriş}

Kızılçam (Pinus brutia Ten.), kuzey yarım kürede, $32^{\circ}$ - $45^{\circ}$ kuzey enlemleri ile $15^{\circ}$ - $45^{\circ}$ doğu boylamları arasında yayılış gösteren bir çam türüdür (Kayacık, 1965). Akdeniz ikliminin tipik ağacı olan kızılçam genel olarak Doğu Akdeniz ülkelerinde yayılış yapmaktadır. Bu yayılışının en batı noktasını İtalya, en doğu noktasını ise Irak olduğu belirtilmektedir (Asmaz, 1993).

Kızılçam, Türkiye'de ki en geniş yayılışını ise Akdeniz iklimine sahip Akdeniz ve Ege bölgelerinde yapmaktadır. Bu bölgelerden başka Marmara bölgesinde ayrıca Karadeniz ile Güneydoğu Anadolu

* ilgili yazar / Corresponding author: emrekuzugudenli@sdu.edu.tr, +90-246-431-4747 
bölgelerinde ise lokal olarak yayılmaktadır (Neyişçi, 1987).

Türkiye'de ki en geniș yayılışa sahip asli çam türü olan kızılçam ormanları, 2.999.684,9 ha normal, 2.420.839,7 degrade (bozuk) olmak, toplam 5.420.524,6 ha alan kaplamaktadır (Anonim, 2015).

Kızılçamın çıkabileceği en üst yükselti (tek ağaç $1500 \mathrm{~m}$ ) Akdeniz bölgesi olup kuzeye doğru gidildikçe bu yükselti azalmaktadır (Marmara bölgesi 600$700 \mathrm{~m}$ ). Araștırma sahası olan Ege Bölgesi'nde ise $800 \mathrm{~m}$ yükseltiye kadar orman vasfinda görülebilmektedir (Atalay, 1983).

Kızılçam, Akdeniz ikliminin hakim olduğu yani yazları sıcak ve kurak, kışları ılık ve yağışlı olan bölgelerde yayılış göstermektedir. Sıcaklık ve ışık isteği yüksek olan kızılçam, donlara karşı hassas olmasından dolayı karasal iklimden kaçınır (Saatçioğlu ve Pamay, 1962).

Türün doğal yayılış alanlarında yıllık ortalama sıcaklık $12-20{ }^{\circ} \mathrm{C}$ arasında değişmektedir. Kızılçamın yayılış alanlarında yağışların yıl içerisindeki dağılımı düzensiz olup, yayılış alanı içerisindeki yıllık ortalama yağış $400 \mathrm{~mm}$ (Burdur, Mut) ile $2000 \mathrm{~mm}$ (Geyik dağları - Aydınkent) arasında değişmektedir. (Atalay vd., 1998).

$\mathrm{Bu}$ çalışmada ülkemiz ormancılı̆̆ı için önemli bir orman ağacı türü olan kızılçamın gelişimi üzerinde etkili olan faktörlerin, çoklu regresyon yöntemi ve orman ekolojisi çalışmaları için henüz yeni olan bulanı mantık yöntemi ile belirlenmesi hedeflenmiştir. Elde edilen sonuçların, araștırma sahasında ve benzer yetişme ortamlarında yapılacak ağaçlandırma çalışmalarına fayda sağlayacağı düşünülmektedir.

Kızılçamın, potansiyel ağaçlandırma sahaları içerisinde gelişimini en iyi yapabildiği alanlara öncelik verilmesi, birim alandan en yüksek verimin elde edilmesini sağlayacaktır. Bu sayede kızılçam dikili ağaç servetinin yaklaşık 270 milyon metreküp (Anonim, 2015) olduğu ülkemizde, daha fazla dikili ağaç servetine daha kısa sürede ulaşılabilecektir.

\section{Bilimsel Yazın Taramas}

Ormanlarımız için verimlilikle ilgili çalışmalar türün ağaçlandırma çalışmalarındaki başarısı ve potansiyel ağaçlandırma sahalarını belirlemek açısından büyük önem arz etmektedir.

Verimlilikten kastedilen örnek alanlarda yer alan hakim (dominant) ağaçların 50 yada 100 yaşına endekslenmiş boy değeridir. Bu değere" bonitet endeksi"denir.

Ülkemizdeki çeşitli orman ağacı türlerinin verimlilikleri ile yetişme ortamı ilişkileri çeşitli bilim insanları tarafından çeşitli yöreler için uzun yıllardır araştırılmaktadır.

Çalışma konusu olan kızılçam ile ilgili kapsamlı ilk çalışmalar Zech ve Çepel (1972) tarafından gerçekleştirilmiştir. Güney Anadolu'da gerçekleştirilen çalışmada toprak ve reliyef özelliklerinin verimlilik üzerindeki etkisi araştırılmıştır. Çalışma sonucunda kızılçamın verimliliğine etki eden en önemli faktörlerinin yamaç konumu, toprağın faydalanabilir su kapasitesi, organik madde miktarı ve $\mathrm{pH}$ olduğu belirlenmiştir.

Kızılçamla ilgili bir diğer çalışma ise Kalay ve arkadaşları (1993) tarafından Orta Karadeniz bölgesinde gerçekleştirilmiş olup kızılçamın boy gelişiminde toprağın kum içeriği, dispersiyon oranı, eğim, yükselti, fizyolojik toprak derinliği, toz- kil miktarı ve tarla kapasitesinin etkili olduğu tespit edilmiştir.

Tetik ve Yeşilkaya (1997) tarafından gerçekleştirilen çalışma ise Antalya yöresinde gerçekleştirilmiştir. Doğal kızılçam ormanlarının verimliliği ile bazı toprak faktörleri arasındaki ilişkiler araştırılmış ve çalışma sonucunda toprağın $\mathrm{pH}$, katyon değişim kapasitesi, organik madde ve toplam $\mathrm{CaCO}_{3}$ içeriğinin kızılçamın verimliliğinde etkili faktörler olduğu belirlenmiştir.

Sütçüler (Isparta) yöresinde gerçekleştirilen çalışmada ise kızılçamın verimliliği üzerinde yükselti, yamaç konumu, eğim, toprak derinliği, Ah horizonunun toz içeriği ve ölü örtü kalınlığının etkili olduğu belirlenmiștir (Özkan ve Kuzugüdenli, 2010).

Özel ve arkadaşları (2011) tarafından Bodrum (Muğla) yöresinde gerçekleştirilen bir çalışmada ise Bakı, Yamaç Durumu, Fizyolojik Toprak Derinliği, Organik Madde Miktarı ve Ortalama Yağış faktörlerinin verimlilik üzerinde etkili olduğu belirlenmiştir.

Antalya yöresinde gerçekleştirilen diğer bir çalışma da ise verimlilik üzerinde en önemli faktörlerin sıcaklık indisi, boylam ve enlem olduğu belirtilmiştir (Çelik ve Özkan, 2015).

Bütün bu çalışmalar incelendiğinde kızılçamın verimliliğinde birçok farklı faktörün etkili olduğu görülmektedir. $\mathrm{Bu}$ çalışmada, verimlilikle ilişkili olduğu düşünülen yetişme ortamı faktörleri belirlenirken, daha önce gerçekleştirilen çalışmaların sonuçlarından faydalanılmıştır.

İstatistiki metot olarak kullanılan bulanık mantık yönteminin insanların düşünme tarzına yakın olması, matematiksel modele ihtiyaç duymaması, sonucunun esnek olması, insana özgü tecrübe ile öğrenme olayının kolay modellenebilmesi ve belirsiz kavramları bile matematiksel olarak ifade edebilmesi gibi özelliklere sahip olmasından dolayı orman ekolojisi çalışmalarında tercih edilebileceği düşünülmüștür.

$\mathrm{Bu}$ çalışma hem bulanık mantık yönteminin orman ekolojisi çalışmalarında ki kullanılabilirliğine örnek 
olması hem de Dalaman ve benzeri yörelerde degrade olmuş kızılçam ormanlarının ağaçlandırma çalışmalarındaki başarısı açısından büyük önem arz etmektedir.

\section{Materyal ve Yöntem}

\subsection{Materyal}

Araştırma sahası Muğla ili, Dalaman yöresidir. Yüzölçümü 752,8 km² dir. İlçe merkezinin denizden yüksekliği $15 \mathrm{~m}$ olup örnek alanların bulunduğu yükseltiler $593 \mathrm{~m}$ ile $798 \mathrm{~m}$ arasında değişmektedir (Şekil 1). Dalaman yöresinin iklimi tipik Akdeniz iklimi olup kışları ılık ve yağışlı, yazları ise kurak ve sıcak geçmektedir. Yörenin uzun yıllara (1977-2017) ait ortalama iklim verileri incelendiğinde, yıllık ortalama sıcaklığı $18,4{ }^{\circ} \mathrm{C}$, en sıcak ay $27,8{ }^{\circ} \mathrm{C}$ ile Temmuz ayı, en soğuk ay ise $10,2^{\circ} \mathrm{C}$ ile Ocak ayı olduğu görülmektedir. Ylllık toplam yağıș ortalaması $810 \mathrm{~mm}$ olup yıllık yağışın \% 52 (417,7 mm)'si kış aylarında (AralıkOcak) düşmektedir. Yaz aylarında (Haziran-TemmuzAğustos-Eylül) düșen yağıș ise yıllık yağıșın \%1'inden daha az olmaktadır. Yörenin yıllık ortalama bağıl nemi ise \% 69'dur (MGM, 2018).

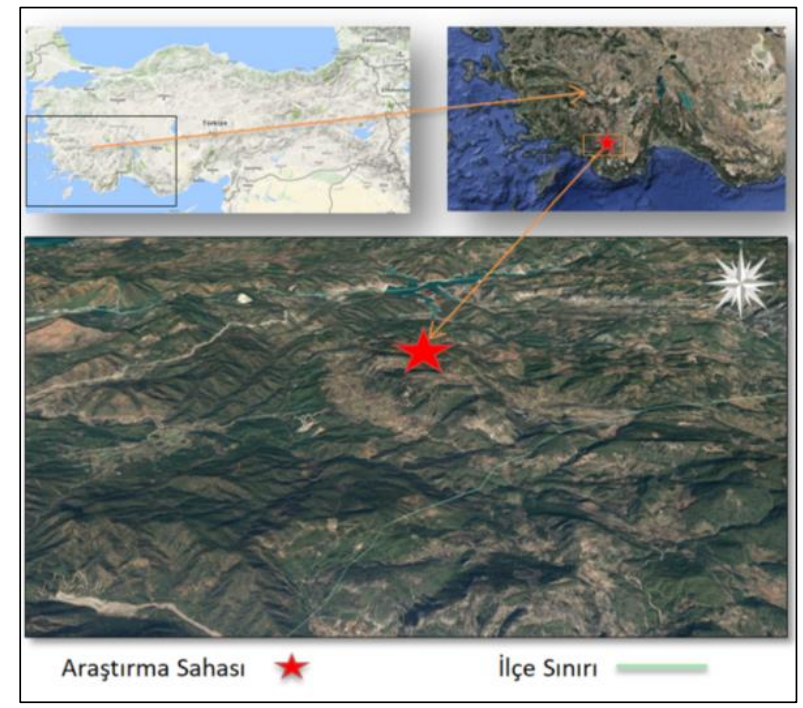

Şekil 1. Araştırma Sahası

Dalaman yöresinin jeomorfolojisi incelendiğinde dağlık alanların hakim olduğu görülmektedir (Şekil 1). Bu dağlardan Çal, Şimşir, Dumlu ve Aygır dağları Güney Batı Toroslar' in uzantısı olup Dalaman-Denizli sınırını olușturmaktadır. Aladağ, Sülüklü, Dalorman, Kızılcabel ve Boztepe dağları ise Fethiye sınırda yer alır. Bunlardan başka güneyde yer alan $\mathrm{Koz}$ ve Kapıdağı ile Dalaman ovasını çevreleyen, Asar, Sandıralı, Karadünek, Akkaya, Kır ve Bayram Dağları yörenin diğer dağlarını oluşturmaktadır. Yöredeki önemli su kaynaklarından olan Dalaman Çayı, 156 km uzunluğunda olup Ortaca-Dalaman sinırını oluşturmaktadır. Yöredeki diğer akarsular Tersakan Çayı, Çal Deresi, Aygır Çayı, Elcik Çayı ve Akçay'dır. Dalaman ovasında Kocagöl (Kargın Gölü), Alagöl,
Bölük, Dalyan (Kaleiçi) ve Badırnaz Gölleri bulunmaktadır. Yöredeki göller ise çoğunlukla Dalaman ovasında toplanmıș olup bunlar Kocagöl (Kargın Gölü), Alagöl, Bölük, Dalyan (Kaleiçi) ve Badırnaz Gölleridir.

Dalaman Çayına karışan vadiler birçok bitki türü için elverişli yetişme ortamı oluşturmuştur. Bu zengin yetişme ortamlarında biyolojik çeşitlilik fazladır. Vadi içlerinde 1500 metrelerde Makedonya meșesi (Quercus trojana Webb.), Kokar ardıç (Juniperus foetidissima Wild.), karaçam (Pinus nigra Arnold.) türleri yoğun olarak görülmektedir. Çalı katmanında ise Crataegus monogyna Jacq., Fraxinus ornus L., Rhus cotinus L., Prunus spinosa L., Lonicera etrusca Santi., Colutea sp., Pyrus communis L., Berberis vulgaris L., Anagyris foetida L., Tamarix sp., Rosa canina L. Qurecus coccifera L., Juniperus oxycedrus L. ve Erica arborea L. gibi bitkiler yer almaktadır. Bunlardan başka Dünya üzerinde tek doğal yayılış alanı Türkiye'nin güneybatısı ile Rodos Adası (Yunanistan) olan sığla ağacına (Liquidambar orientalis Miller.), Dalaman Çayı boyunca iç kısımlarda doğal olarak rastlanmaktadır (Coşkun, 2017).

$\mathrm{Bu}$ taksonlardan etnobotanik kullanımları incelendiğinde en çok Lamiaceae, Rosaceae, Fabaceae, Liliaceae and Apiaceae familyalarının kullanıldığ belirtilmektedir (Sağıroğlu vd., 2013)

\subsection{Yöntem}

Araştırma büro ve arazi çalışmaları olmak üzere 2 kısımdan meydana gelmiştir. İlk olarak büroda dijital orman haritaları üzerinde araștırma sahasını temsil edebilecek potansiyel örnek alanlar belirlenmiştir. Sonrasında bu alanlara bir keşif gezisi yapılarak örnek alanların yerleri kesinleștirilmiștir.

Örnek alanlar normal kapalılıkta, 400m² (20x20m) büyüklügüunde ve saf kızılçam meşcerelerinden seçilmiştir (Özkan ve Kuzugüdenli, 2010).

Meşcere gelişim ölçüsü olarak üst boy seçilmiştir. Çünkü serbest büyümüş ağaçların boyu, yetiştiği çevrenin verim gücünü diğer ölçü değerlerine kıyasla çok daha iyi yansıtmakta ve ağaçların boyu meşcere sıklığından daha az etkilenmektedir. Bu nedenlerle meşcere gelişim ölçüsü olarak üst boy kullanılmıştır (Firat, 1972).

Bağımlı değişken olan bonitet endeksini (100 yaşındaki üst boy) belirlemek amacıyla hektarda 100 ağaç hesabına göre örnek alanlar içerisinde en üst boya sahip ve düzgün gövdeli 4 ağaç üzerinde boy ve yaş ölçümleri yapılmıştır.

Örnek alan içerisinde ölçülen 4 ağacın boy değeri kızılçam hasılat tablosu (Alemdağ, 1962) yardımıyla 100 yaşına enterpole edilmiş ve bu ağaçların ortalamaları alınmak suretiyle her örnek alanın bonitet endeks değeri belirlenmiştir. Enterpolasyon işlemi, yaş değişkeninin üst boy üzerindeki etkisini ortadan kaldırmak ve yaș dıșındaki diğer faktörlerin üst boy üzerindeki etkilerini belirlemek amacıyla 
gerçekleștirilmiştir (Özkan, 2004; Özkan ve Kuzugüdenli, 2010).

Araştırmanın bağımsız değişkenlerini ise örnek alanların yer aldığı yetişme ortamlarına ait enlem, boylam, yükselti, bakı, eğim, arazi formu, yamaç konumu, sıcaklık, yağış ve büyük toprak grubu oluşturmuştur.

İklim değişkenlerinden uzun yıllara ait (1977-2017) ortalama yıllık sıcaklık ve ortalama yıllık toplam yağış verileri kullanılmıştır (MGM, 2018). Örnek alanlara ait iklim verileri, Dalaman meteoroloji istasyonuna ait iklim verilerinin bu alanlara enterpole edilmesiyle belirlenmiştir. Sicaklı enterpolasyonunda "yükseldikçe sıcaklık her 200 metrede 1 derece azalır" kuralı uygulanmıştır.

Yağış eterpolasyonunda ise Dönmez (1990) tarafından kullanılan Huber formülünden faydalanılmıştır (Eşitlik 1).

$\mathrm{Ph}=\mathrm{Po}+41,4 \mathrm{~h}+382 \mathrm{Tga}$

(Ph yağışı bulunacak yer, Po mukayese edilen istasyonun yağışı, 41,4 her 100 metredeki yağış artış katsayısı, h hektometre olarak yükselti farkı, Tga yamaç eğim derecesinin tanjant değeri)

Fizyografik faktörleden enlem ve boylam değerleri GPS yardımıyla, yükselti klizimetre, bakı pusula yardımıyla ölçülmüştür.

Toprak özelliklerinden örnek alanlara ait büyük toprak grupları değişkeni Toprak Muhafaza ve Zirai Sulama Genel Müdürlüğünce hazırlanan 1/25000 ölçekli toprak haritasının sayısallaştırılması ile tespit edilmiştir.

Değişkenlerin çoğu istatistik analize elde edildiği şekli ile sokulmuş fakat büyük toprak grupları, yamaç konumu, bakı ve arazi formu değişkenleri aşağıdaki gibi sayısallaştırılmıştır. Toprak grupları değişkeni Kireçsiz Kahverengi Orman Toprağı (1), Kırmızı Kahverengi Akdeniz Toprağı (2) ve Kırmızı Akdeniz Toprağı (3) şeklinde sayısallaştırılmıştır. Yamaç konumu değişkeni, sırt (1), üst yamaç (2), orta yamaç (3), alt yamaç (4), vadi dip kısmı taban arazi (5) şeklinde sıra istatistiği uygulanarak sayısal hale getirilmiştir (Daşdemir, 1992; Özkan vd. 2008). Bakı değişkeni Özkan ve Kuzugüdenli (2010) tarafindan yapıldığı şekliyle, kuzeyden itibaren başlanarak her iki yöne eşit açlara aynı değeri vermek suretiyle elde edilmiştir. Yani, kuzey=1, kuzeydoğu ve kuzeybatı=2, doğu ve batı=3, güneydoğu ve güneybatı=4 ve güney=5 değerini almıştır. Arazi formu ise iç bükey=1, dış bükey=2, düz=3 ve dalgalı=4 olacak şekilde sayısal hale getirilmiştir.

Elde edilen verilerin değerlendirilmesi amacıyla, SPSS paket programında, basit korelasyon, basit regresyon ve çoklu regresyon analizi (Özdamar, 1997) ile Matlab programında ise bulanık mantık yöntemi kullanılmıştır.
İlk olarak basit regresyon analizi kullanılmıştır. $\mathrm{Bu}$ analiz ile bonitet endeksi ile bağımsız değişkenler arasındaki ikili ilişkiler belirlenmiştir.

Sonrasında çoklu doğrusal bağlantı problemini ortadan kaldırmak ve bağımsız değişkenler arasındaki ikili ilişkileri incelemek maksadıyla korelasyon analizi yapılmıştır. Birbiriyle yüksek korelasyona sahip çoklu doğrusal bağlantı problemi oluşturan değişkenler belirlenerek ilerleyen modelleme aşamalarından muaf tutulmuşlardır. Çalışmada Pearson ve Spearman olmak üzere iki tip korelasyon analizi kullanılmıştır. Pearson korelasyon analizi bonitet endeksi ile sürekli veri içeren değişkenler arasında uygulanmıştır. Spearman korelasyon analizi ise bonitet endeksi ile kategorik bağımsız değişkenler olan toprak grubu, bakl, arazi formu ve yamaç konumu arasında uygulanmıştır.

Çoklu regresyon analizi, bir bağımlı değişken ile birden çok bağımsız değişken arasında gerçekleştirilmekte ve regresyon denklemleri adı verilen matematiksel fonksiyonları içermektedir. Çoklu regresyon analizinde temel amaç, ele alınan değişkenlerle matematiksel model oluşturmak ve bağımlı değişkende meydana gelen değişimin ne kadarının bağımsız değişkenler tarafından açıklandığını belirlemektir. Burada ölçümü zor olan Y bağımlı değişkeni, $\mathrm{X}_{1}, \mathrm{X}_{2}, \mathrm{X}_{3} \ldots . . . \mathrm{X}_{\mathrm{n}}$ ise ölçümü kolay olan bağımsız değişkenler olarak adlandırılmaktadır. $\mathrm{Bu}$ şekilde oluşturulan regresyon modeli ile; $\mathrm{Y}=\mathrm{f}\left(\mathrm{X}_{2}, \mathrm{X}_{3} \ldots .\right.$. $X_{n}$ ) şeklindeki fonksiyonel ilişkiler ortaya konmaktadır (Kalıpsız, 1981).

Bulanık mantık modelleme kavramı ilk olarak Lütfi A. Zadeh tarafından ortaya konulmuştur (Zadeh, 1965). Klasik (geleneksel) mantıkla, herhangi bir nesne o kümeye ya aittir ya da değildir. Bu kisaca 0 ve 1 mantığıdır. Şekil 2'de görüldüğü üzere $0-15{ }^{\circ} \mathrm{C}$ arasındaki sıcaklıklar soğuk, $15-30{ }^{\circ} \mathrm{C}$ arasındaki sıcaklıklar ise sıcak sınıfına girmektedir.

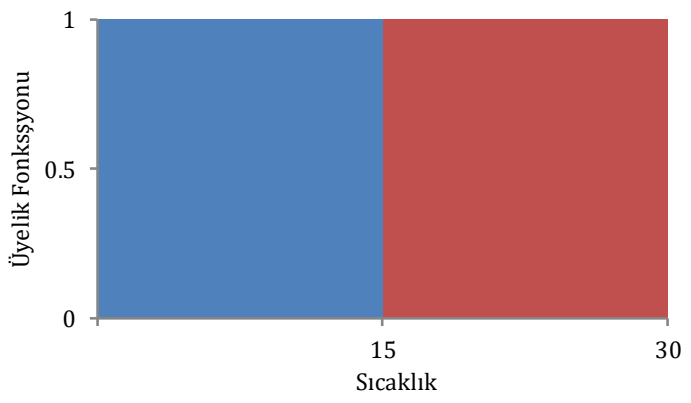

Şekil 2. Klasik mantığa göre sıcaklık örneği

Bu kurallara göre $16{ }^{\circ} \mathrm{C}$ olan bir yer sıcak sayılırken 14 ${ }^{\circ} \mathrm{C}$ olan bir yer ise soğuk sayılmaktadır. Bu durumu bulanık mantık açısından incelersek Şekil 2'de görüleceği gibi $16{ }^{\circ} \mathrm{C}$ olan bir yer belirli bir oranda sicak sayılırken belirli bir oranda ise soğuk sayılmaktadır. Bulanık mantıkta klasik mantıktaki gibi 0 ve 1 mantığı yoktur, günlük yaşantıda kullandığımız gibi daha esnek bir yaklaşım vardır (Şen, 2009). 


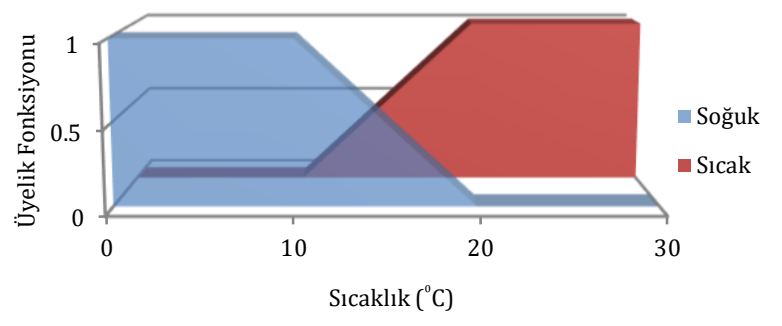

Şekil 3. Bulanık mantığa göre sıcaklık örneği

Bulanık mantık denetleyici; bulanıklaştırma, kural tabanlı çıkarım mekanizması ve durulaştırma olmak üzere üç temel kısımdan oluşmaktadır. Bulanıklaştırma biriminde giriş değişkenlerinin değerine karşılık gelen üyelik fonksiyonlarının 0 ile 1 aralığındaki üyelik dereceleri belirlenir. Kural tabanlı çıkarım mekanizması biriminde, bulanıklaştırma biriminden gelen üyelik dereceleri sözel kurallara göre değerlendirilerek bulanık sonuçlar elde edilir. Uzman kişiler tarafından sözel kurallara bağlı olarak oluşturulan kural tabanlı çıkarım mekanizması bulanık mantık denetleyici tasarımının en önemli kısmını olușturmaktadır. Bu yapı içerisindeki her bir kural, denetlenmek istenen sistemin belirli bir kısmına karşılık gelecek bir kontrol sağlamaktadır. Tüm kuralların birlikte kullanılmasıyla sistem modelinin tamamını ifade eden bir kural tabanı ortaya çıkarılmaktadır. Durulaştırma biriminde kural tabanlı çıkarım mekanizmasından gelen bulanık ifadelerin toplamı sisteme uygulanabilecek sayısal ifadelere dönüştürülür (Anand ve Tyagi, 2012).

\section{Araştırma Bulguları}

Bonitet Endeksi ile bağımsız değișkenler arasında yapılan basit regresyon analizi sonuçlarına göre bonitet endeksi ile yükselti, sıcaklık, yağış ve toprak grubu değişkenlerinin istatistiksel olarak anlamlı ilişkisi olduğu ortaya çıkmıştır $(\mathrm{p}<0,05)$.

Çoklu doğrusal bağlantı, regresyon katsayılarının yanlış tahmin edilmesine, regresyon katsayılarının standart hatalarının abartılı çıkmasına buna bağlı olarak güven aralıklarının büyümesine sebep olabilir. Modellemelerin sağlıklı olabilmesi için çoklu doğrusal bağlantı sorununun varsa tespit edilerek ortadan kaldırılması gerekmektedir. Çoklu doğrusal bağlantının olup olmadığını tespit etmek için çoğunlukla bağımsız değișkenler arasındaki korelasyon değerine bakılır. $\mathrm{Bu}$ değişkenler arasındaki yüksek korelasyon değerleri çoklu bağlantı probleminin varlığının habercisi olabilmektedir (Alpar, 1997).

$\mathrm{Bu}$ araştırmada çoklu doğrusal bağlantı problemi oluşturacak değişkenleri belirlemek amaciyla bağımsız değişkenler arasında basit korelasyon analizi yapılmıştır (Hines ve Montgomery, 1990). Analiz sonucunda yükselti ve sıcaklık değişkenlerinin birbirleriyle yüksek korelasyona $\left(0,996^{* *}\right)$ sahip olduğu görülmüș ve sıcaklık yerine yükselti değișkeni ile yola devam edilmesine karar verilmiștir (Kuzugüdenli, 2014).

Araştırma sahası içerisinde kızılçam 500 m'den 800 m'ye kadar yayılmıştır. Yükseklik ile bonitet endeksi arasındaki regresyon analizi incelendiğinde yüksekliğin artışına bağlı olarak bonitet endeksinde düşüş meydana geldiği görülmektedir (Şekil 4).

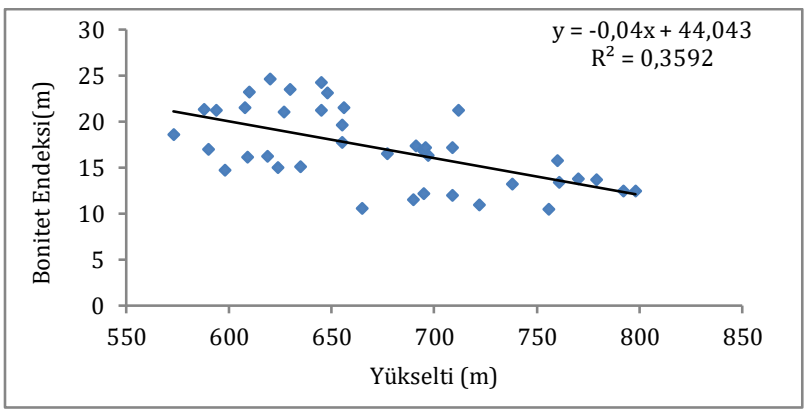

Şekil 4. Bonitet endeksi ile yükselti ilişkisi

Yağışın örnek alanlardaki dağılımına bakıldığında $1250 \mathrm{~mm}$ ile $1650 \mathrm{~mm}$ arasında dağıldığ görülmektedir. Yağıș ile bonitet endeksi arasındaki değişim incelendiğinde, yağışın artışına bağlı olarak bonitet endeksinde azalma olduğu görülmektedir (Şekil 5).

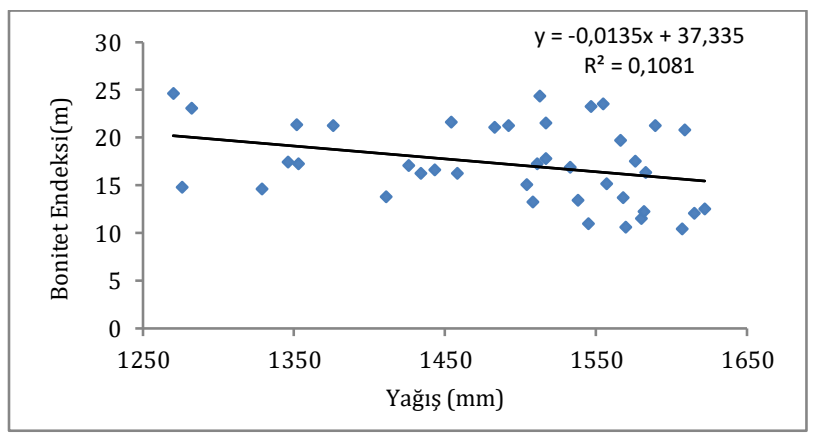

Şekil 5. Bonitet endeksi ile yağış iliş̧kisi

Araştırma sahasının toprak grupları incelendiğinde örnek alanlar içerisinde 3 büyük toprak grubu görülmektedir. Bu gruplar Kireçsiz Kahverengi Orman Toprağı (1), Kırmızı Kahverengi Akdeniz Toprağı (2) ve Kırmızı Akdeniz Toprağı (3) şeklindedir. Toprak grupları ile bonitet endeksi arasındaki değişim incelendiğinde, kireçsiz kahverengi orman toprağının (1) en düşük kırmızı Akdeniz toprağının (3) ise en yüksek bonitet endeks değerlerine sahip olduğu görülmektedir (Şekil 6). 


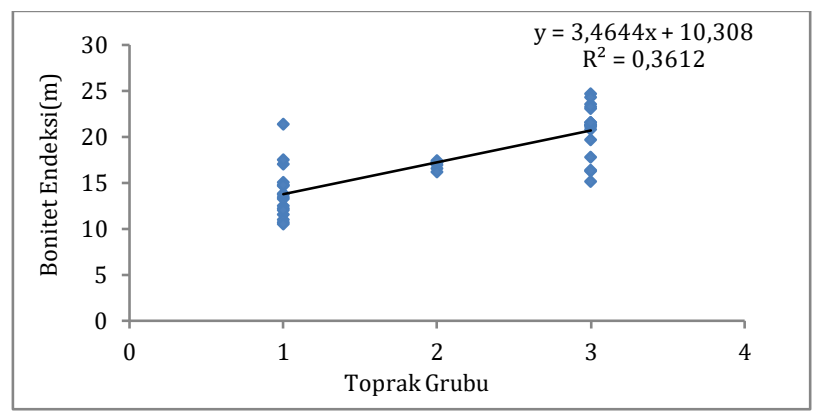

Şekil 6. Bonitet endeksi ile toprak grubu ilişkisi

Yükselti, yağış ve toprak grubunun bonitet endeksi üzerindeki ikili ilişkileri basit regresyon analiziyle incelendikten sonra çoklu regresyon analizi ile bu değişkenlerin bonitet endeksi üzerindeki toplu etkisi araştırılmıştır. Bonitet endeksi ile yükselti, yağış ve toprak grubu değişkenleri arasında yapılan çoklu regresyon analizi sonucunda istatistiksel olarak anlamlı $(0,001<\mathrm{p})$ ve $\mathrm{R}^{2}$ değeri 0,46 olan matematiksel bir denklem elde edilmiştir (Eşitlik 2).

Bonitet Endeksi(m) = 47,9 - (0,005 x Yağış $)-(0,038$ x Yükselti) + (0,95xBüyük Toprak Grubu)

Elde edilen denklemden faydalanılarak bonitet endeks değerinin kestirim değerleri belirlenmiștir. (Şekil 7).

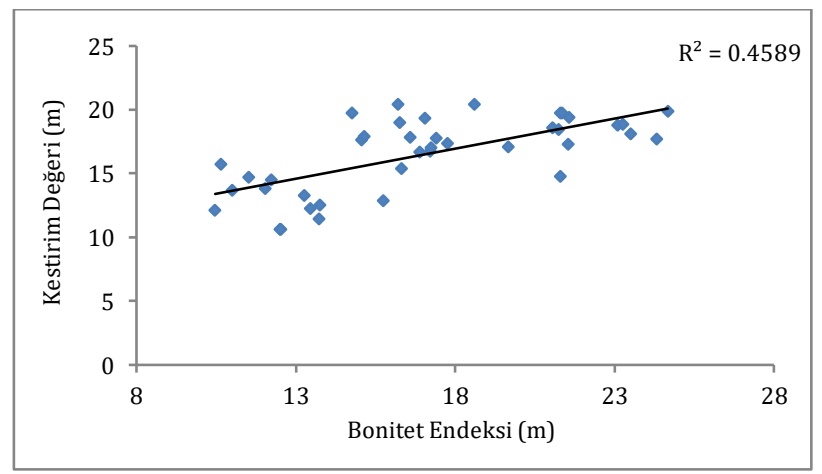

Şekil 7. Bonitet endeksi ve kestirim değerlerinin ilişkisi

Regresyon modeli oluşturulduktan sonra aynı değişkenlerle Sugeno tipi bulanık mantık modellemesi yapılmıştır. Girdi değişkenleri olarak yükselti, yağış ve toprak grubu çıktı değişkeni olarak ise bonitet endeksi belirlenmiştir.

Yükselti değişkeni için üyelik fonksiyonu belirlenirken yarı ikizkenar yamuk ve üçgen üyelik fonksiyonları kullanılmıştır. Yükselti değişkeni düşük, orta ve yüksek şeklinde toplam 3 adet üyelik fonksiyonu belirlenmiştir (Şekil 9).

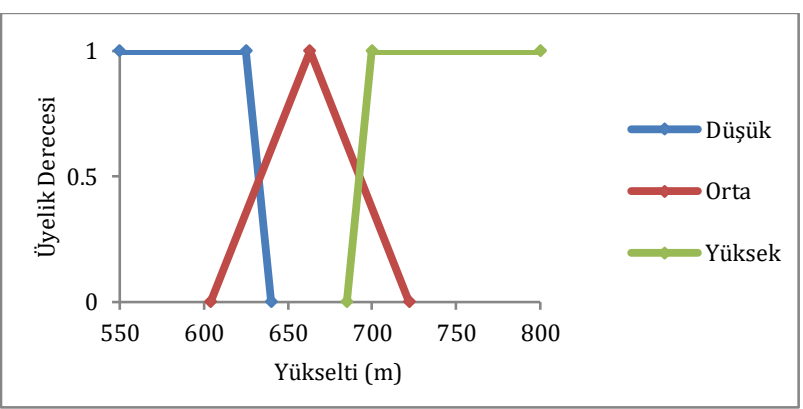

Şekil 9. Yükseltiye ait üyelik fonksiyonları

Yağış değişkeni için üyelik fonksiyonu belirlenirken yarı ikizkenar yamuk ve üçgen üyelik fonksiyonları kullanılmıştır. Yağış değişkeni için düşük, normal ve yüksek şeklinde toplam 3 adet üyelik fonksiyonu belirlenmiştir (Şekil 10).

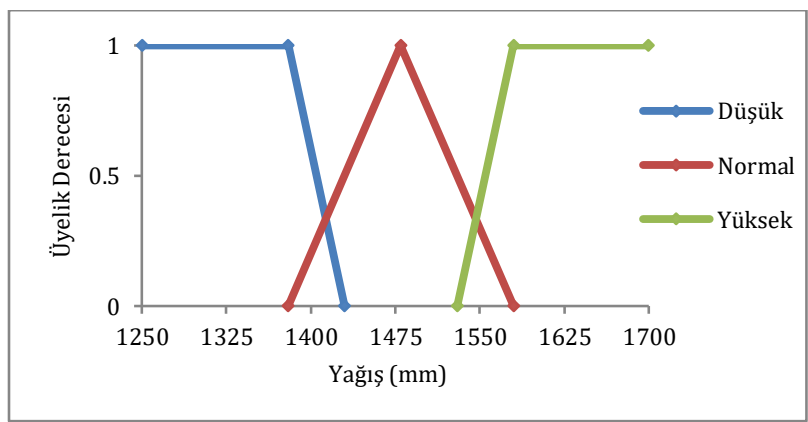

Şekil 10. Yağışa ait üyelik fonksiyonları

Toprak grupları değişkeni için üyelik fonksiyonu belirlenirken yine yarı ikizkenar yamuk ve üçgen üyelik fonksiyonları kullanılmıştır. Toprak grubu değişkeni için Kireçsiz Kahverengi Orman Toprağı (1), Kırmızı Kahverengi Akdeniz Toprağı (2) ve Kırmızı Akdeniz Toprağı (3) şeklinde toplam 3 adet üyelik fonksiyonu belirlenmiștir (Şekil 11).

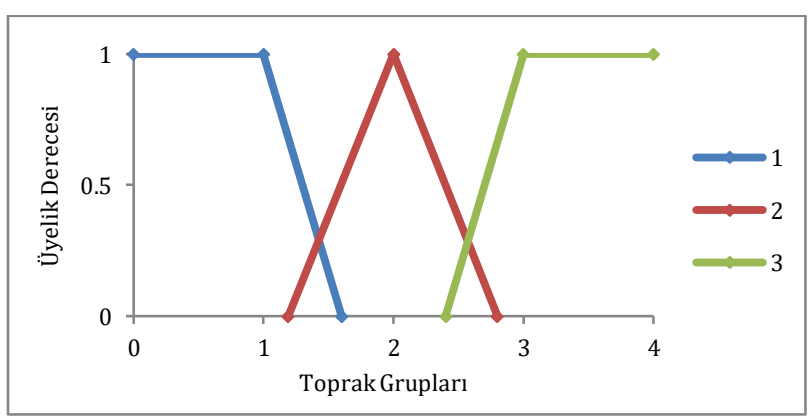

Şekil 11. Toprak gruplarına ait üyelik fonksiyonları

Çıktı değişkeni olan bonitet endeksi değişkeni için üyelik fonksiyonu belirlenirken yarı ikizkenar yamuk ve üçgen üyelik fonksiyonları kullanılmıştır. Bonitet endeksi değișkeni kötü, orta ve iyi șeklinde toplam 3 adet üyelik fonksiyonu belirlenmiștir (Şekil 12). 


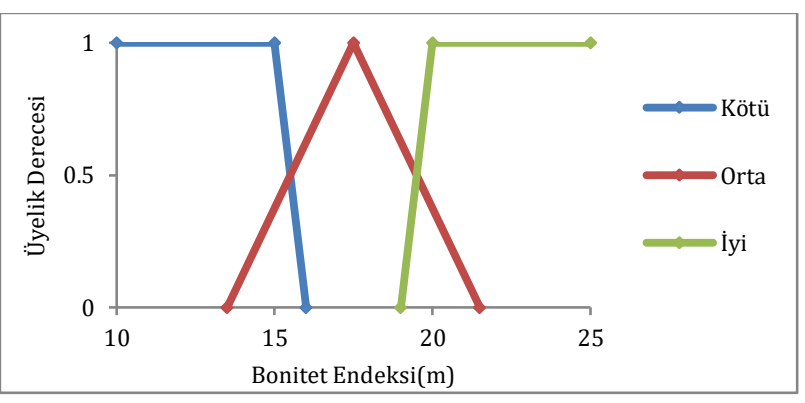

Şekil 12. Bonitet endeksine ait üyelik fonksiyonları

Üyelik fonksiyonları belirlendikten sonra kuralların yazılmasına geçilmiştir. Kurallar belirlenirken değişkenler arasındaki ilişkiler, arazi de gerçekleștirilen gözlemler ve literatürden faydalanılmıştır. Toplam 27 adet kural oluşturulmuş olup Tablo 1'de verilmiștir.

Tablo 1. Bulanık mantık için oluşturulan kurallar

\begin{tabular}{|c|c|c|c|c|}
\hline KURAL & YÜKSELTİ & YAĞIȘ & TOPRAK GRUBU & $\begin{array}{l}\text { BONITET } \\
\text { ENDEKSI }\end{array}$ \\
\hline 1 & Düşük & Düşük & 1 & Kötü \\
\hline 2 & Düşük & Normal & 2 & Orta \\
\hline 3 & Düşük & Yüksek & 3 & Yüksek \\
\hline 4 & Orta & Düşük & 1 & Kötü \\
\hline 5 & Orta & Normal & 2 & Orta \\
\hline 6 & Orta & Yüksek & 3 & Orta \\
\hline 7 & Yüksek & Düşük & 1 & Kötü \\
\hline 8 & Yüksek & Normal & 2 & Orta \\
\hline 9 & Yüksek & Yüksek & 3 & Orta \\
\hline 10 & Düşük & Düşük & 3 & Orta \\
\hline 11 & Düşük & Normal & 1 & Orta \\
\hline 12 & Düşük & Yüksek & 2 & Kötü \\
\hline 13 & Orta & Düşük & 3 & Orta \\
\hline 14 & Orta & Normal & 1 & Kötü \\
\hline 15 & Orta & Yüksek & 2 & Yüksek \\
\hline 16 & Yüksek & Düşük & 3 & Orta \\
\hline 17 & Yüksek & Normal & 1 & Kötü \\
\hline 18 & Yüksek & Yüksek & 2 & Orta \\
\hline 19 & Düşük & Düşük & 2 & Yüksek \\
\hline 20 & Düşük & Normal & 3 & Orta \\
\hline 21 & Düşük & Yüksek & 1 & Orta \\
\hline 22 & Orta & Düşük & 2 & Yüksek \\
\hline 23 & Orta & Normal & 3 & Orta \\
\hline 24 & Orta & Yüksek & 1 & Kötü \\
\hline 25 & Yüksek & Düşük & 2 & Yüksek \\
\hline 26 & Yüksek & Normal & 3 & Orta \\
\hline
\end{tabular}

\begin{tabular}{|c|c|c|c|c|}
\hline 27 & Yüksek & Yüksek & 1 & Düşük \\
\hline
\end{tabular}

Kurallar olușturulduktan sonra bulanık mantık denetleyicisinin son aşaması olan durulaştırma bölümüne geçilmiştir. Bu bölümde durulaștırma yöntemi olarak ağırlık merkezi (centroid of area) yöntemi kullanılmıştır.

Bulanık mantık modellemesi ile bonitet endeksinin kestirim değerleri elde edilmiştir. Elde edilen kestirim değerlerinin tahmin gücünü belirlemek amaciyla kestirim değerleri ile gerçek değerler arasında regresyon analizi yapılmıştır. Yapılan regresyon analizi sonucunda $\mathrm{R}^{2}=0,6845$ bulunmuştur (Şekil 13).

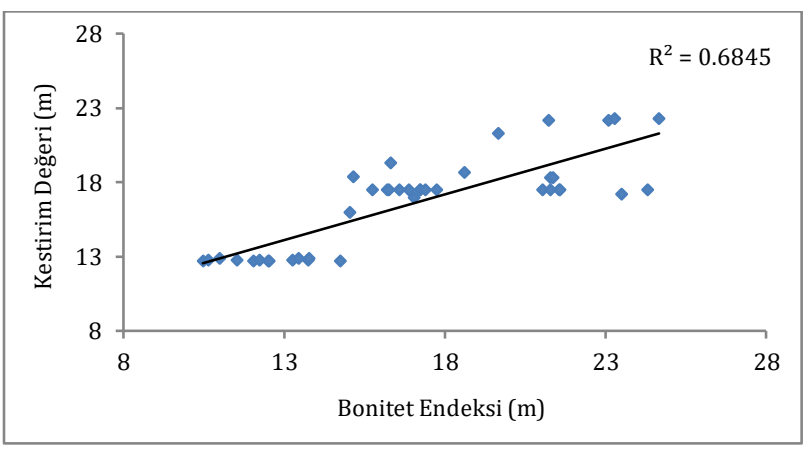

Şekil 13. Bonitet endeksi ve kestirim değerlerinin ilişsisi

\section{Sonuç ve Tartışma}

$\mathrm{Bu}$ çalışma bulanık mantık yönteminin orman ekolojisi çalışmalarında ki kullanılabilirliğinin gösterilmesi ve Dalaman yöresi civarında yer alan toplam 283.773 ha degrade olmuș orman alanının ağaçlandırma çalışmalarındaki başarısını artırmak amacıyla gerçekleştirilmiştir.

$\mathrm{Bu}$ amaçla araştırma sahası olan Dalaman yöresinde 40 örnek alan belirlenmiştir. Bağımlı değişken olan bonitet endeksini belirlemek amaciyla her örnek alanda üst boy ve yaş ölçümleri yapılmıştır. Araştırmanın bağımsız değişkenleri için de örnek alanlarda enlem, boylam, yükselti, bakı, eğim, arazi formu, yamaç konumu, sıcaklık, yağış ve büyük toprak grubu değişkenleri belirlenmiştir.

Bonitet endeksi ile bağımsız değişkenler arasındaki ikili ilişkileri belirlemek amacıyla basit regresyon analizi kullanılmıştır. Analiz sonucunda bonitet endeksi ile yükselti, sıcaklık, yağış ve toprak grubu değişkenlerinin istatistiksel olarak anlamlı ilişkisi olduğu ortaya çıkmıştır $(\mathrm{p}<0,05)$.

Çoklu doğrusal bağlantı problemi oluşturacak değişkenleri belirlemek amacıyla bağımsız değişkenler arasında basit korelasyon analizi yapılmıştır. Analiz sonucunda Yükselti ve Sıcaklık değișkenlerinin birbirleriyle yüksek korelasyona $\left(0,996^{* *}\right)$ sahip olduğu görülmüş sicaklık yerine 
yükselti değişkeni ile yola devam edilmesine karar verilmiștir.

Yükselti, Yağıș ve Toprak grubunun bonitet endeksi üzerindeki ikili ilişkileri basit regresyon analiziyle incelendikten sonra çoklu regresyon analizi ile bu değişkenlerin bonitet endeksi üzerindeki toplu etkisi belirlenmiştir $\left(\mathrm{R}^{2}=0,46\right)$

Yükseltinin artışına bağlı olarak bonitet endeksinde düşüş olmasının sıcaklıktan kaynaklandığı düșünülmektedir. Şöyle ki, sıcaklık ve ıșık isteği yüksek olan kızılçamın, yükselti artışına bağlı olarak sıcaklıkta meydana gelen düşüşten olumsuz etkilendiği, neticesinde de bonitet endeksinin yükseltinin fazla olduğu yerlerde düşük olduğu görülmektedir (Günal, 1997). Benzer sonuçlar Özkan ve Kuzugüdenli (2010) tarafından Sütçüler yöresinde yetişen kızılçamın verimliliğinin araştırıldığı çalışmada da tespit edilmiştir.

Ayrıca Ege Bölgesi'nde 800m yükselti kızılçamın orman doğal sınırının (saf meşcere) üst notasını oluşturmaktadır. Üst sınıra yakın yerlerde meydana gelen bazı olumsuz yetişme ortamı koşullarından (kayalık sahalar, erozyon, olumsuz hava koşulları vd.) dolayı kızılçamın $800 \mathrm{~m}$ yükseltiye yakın yerlerde genellikle iyi bir gelişme göstermesi beklenmemektedir (Genç, 2004).

Yağış artışına bağlı olarak bonitet endeksinde görülen kısmi düşüşün yine yükseltiyle ilişkili olduğu düşünülmektedir. Zech ve Çepel (1972) tarafından gerçekleștirilen bir çalışmada da alçak ve sıcak bölgelerde yetișen kızılçamın yüksek ve serin bölgelerde yetișen kızılçamlara kıyasla daha iyi bir gelişme gösterdikleri bildirilmiştir.

Araştırma sahası üzerinde 3 farklı toprak grubuna rastlanmıştır. Yapılan basit regresyon analizi sonucunda bonitet endeksi değerleri en düşük olan toprak grubunun kireçsiz kahverengi orman topraklarında olduğu görülmektedir (Şekil 6).

Kireçsiz kahverengi orman toprakları, genellikle yüksek ve yağıșın fazla olduğu yerlerde gelișmektedir. $\mathrm{Bu}$ topraklar kahverengi orman topraklarının yıkanması sonucu, topraktan kirecin uzaklaşmasıyla oluşur (Günal, 2003). Araştırma sahasında yükselti ve yağışın fazla olduğu yerlerde verimlilik düşüktür. Yükselti ve yağışa bağlı olarak burada gelişen topraklarında genel olarak kireçsiz kahverengi orman toprağı olması bu toprakların verimliliğinin düşük olmasını açıklamaktadır.

Kırmızı Akdeniz Toprağı Akdeniz iklimine özgü kırmızı renkli topraklardır. Kalker kayaçlar üzerinde görülen bu topraklar özellikle kil ve demiroksit içeriği bakımından oldukça zengindir. Kalker kayaçların çatlaklı yapıya sahip olmasından dolayı bu çatlaklara balçık dolmakta ve neticesinde kızılçam için zengin bir beslenme ortamı oluşmaktadır (Öktem, 1987). Kızılçamın beslenme ortamındaki bu zenginleşmeden dolayı bu topraklarda bonitet endeksi yüksek olabilmektedir.

Bulanık mantık modellemesinin tahmin gücünün $\left(\mathrm{R}^{2}=0,6845\right)$ regresyon modellemesine $\left(\mathrm{R}^{2}=0,4589\right)$ oranla çok daha yüksek olması, orman ekolojisi çalışmalarında alternatif bir metot olarak kullanılma potansiyelinin bulunduğunu göstermektedir. Orman ekosistemlerinin açık sistemler olması ve bulanık mantık modellemesinin bu açık sistemdeki ilişkileri daha fazla dikkate alması, elde edilen sonuçların regresyon modelinden daha tatmin edici olduğunu göstermektedir (Özkan, 2013).

\section{Çıkar Çatışması}

Yazar tarafından herhangi bir çıkar çatışması beyan edilmemiştir.

\section{Kaynaklar}

Alemdağ, Ş., $\quad$ 1962. Türkiye'deki Kızlçam Ormanlarının Gelişimi, Hasılatı ve Amenajman esasları. Ormcılık Araștırma Enstitüsü Teknik Bülten No: 2, 160 s., Ankara.

Alpar, R., 1997. Uygulamalı Çok Değişkenli İstatistiksel Yöntemler Giriş-I. Kültür Ofset, Ankara.

Anand, M. S., Tyagi, B., 2012. Design and Implementation of Fuzzy Controller on FPGA", International Journal of Intelligent Systems and Applications, 4(10), 35-42.

Anonim, 2015. Türkiye Orman Varlığı. Orman Genel Müdürlüğü Yayınları, 33 s., Ankara.

Asmaz, H., 1993. Akdeniz Peyzajında Kızılçamın Önemi. Uluslararası Kızılçam Sempozyumu, 18-23 Ekim 1993, Bildiriler Kitabı, 48-55, Marmaris.

Atalay, İ., 1983. Türkiye Vejetasyon Coğrafyasına Giriş (Vol. 19). Ege Üniversitesi Edebiyat Fakültesi, Yayın No:19.

Atalay, İ., Sezer, İ., Çukur, H., 1998. Kızılçam (Pinus brutia Ten.) Ormanlarının Ekolojik Özellikleri Ve Tohum Nakli Açısından Bölgelere Ayrılması. Orman Ağaçları ve Tohumları Islah Araştırma Müdürlüğü, Yayın No.6, 108 s., Ege Üniversitesi Basım Evi, İzmir.

Coşkun, S., 2017. Büyük Menderes Nehri ile Yukarı Dalaman Çayı Arasındaki Sahada Bitki Örtüsünün Coğrafi Dağılışı. Journal of International Social Research, 10(49).

Çelik, H., Özkan, K., 2015. Antalya Ovacık Dağı Yöresi'nde Kızılçam (Pinus brutia Ten.)'ın Gelişimi ile Yetişme Ortamı Özellikleri Arasındaki İlişkiler. Süleyman Demirel Üniversitesi Fen Bilimleri Enstitüsü Dergisi, 19(2), 190-197. 
Daşdemir, İ., 1992. Türkiye'deki Doğu Ladini (Picea orientalis L. Carr.) Ormanlarında Yetişme Ortamı Faktörleri-Verimlilik İlişkisi. Ormancilık Araştırma Enstitüsü Yayınları, No: 64, Ankara, 66 s.

Dönmez, Y., 1990. Umumi Klimatoloji ve İklim Çalıșmaları, İstanbul Üniversitesi Yayın No: 36483248, İstanbul.

Firat, F., 1972. Orman Hasılat Bilgisi. İstanbul Üniversitesi Orman Fakültesi Yayın No 1541/166, 191s, İstanbul.

Genç, M., 2004. Silvikültürün Temel Esasları, SDÜ Orman Fak., Yayın No:44, Isparta.

Günal, N., 1997. Türkiye'de Başlıca Ağaç Türlerinin Coğrafi Yayılışları, Ekolojik ve Floristik Özellikleri, Çantay Kitapevi, s. 22, İstanbul.

Günal, N., 2003. Yukarı Gediz Havzasının Bitki Coğrafyası, Çantay Kitabevi, Melisa Matbaacılık, İstanbul.

Hines, W. W., Montgomery, D. C., 1990. Probability and Statistics in Engineering and Management Science. John Wiley \& Sons, Inc.

Kalay, H. Z., Yavuz, H., Karagül, R., Altun, L., Tüfekçioğlu, A., 1993. Kızılçam'ın Orta Karadeniz Bölümü Arazisinde Dikey ve Yatay Yayılışının Bitki Kuşakları ve Türleri Bakımından Ekolojik İncelenmesi, Uluslararası Kızılçam Sempozyumu Bildiriler Kitabı, 18-23 Ekim 1993, Marmaris, Türkiye, 117-128.

Kalıpsız, A. 1981. İstatistik Yöntemler, İstanbul Üniversitesi Orman Fakültesi Yayın No: 2837/294, $558 \mathrm{~s}$.

Kayacık, H., 1965. Orman ve Park Ağaçlarının Özel Sistematiği Gymnospermae (Açık Tohumlular) I. Cilt. İstanbul Üniversitesi Orman Fakültesi Yayın No: 1105/98, 390s. İstanbul.

Kuzugüdenli, E., 2014. Batı Akdeniz Bölgesinde Boylu Ardıçın (Juniperus excelsa Bieb.) Boy Gelișimi ile Bazı Yetişme Ortamı Faktörleri Arasındaki İlişkiler. Yayınlanmamış Doktora Tezi. Süleyman Demirel Üniversitesi, Türkiye.

MGM, 2018. 1975-2017 Yılları Arasında Muğla (Dalaman) Yöresine Ait Çok Yıllık İklim Verileri, T.C. Çevre ve Orman Bakanlığı Devlet Meteoroloji İşleri Genel Müdürlüğü, Ankara

Neyişçi, T., 1987. Kızılçamın Ekolojisi. Kızılçam El Kitabı Dizisi-2, Ormancılık Araştırma Enstitüsü Yayınları, Muhtelif Yayınlar Dizisi:52, 23-56, Ankara.

Öktem, E., 1987. Kızılçam El Kitabı Dizisi: 2. Ormancılık Araștırma Enstitüsü Yayınları, Muhtelif Yayınlar Serisi, 52, 11-57.
Özdamar, K., 1997. Paket Programlar ile İstatistiksel Veri Analizi. Anadolu Üniversitesi Yayınları, Eskișehir. I. 493.

Özel, H.B., Kırdar, E., Demirci, A., Görmez, Y., 2011. Bazı Yetişme Ortamı Koşulları ile Kızılçam (Pinus brutia Ten.) Fidanlarının Büyüme Performansı Arasındaki İlişkiler. I. Ulusal Akdeniz Orman ve Çevre Sempozyumu, 26-28 Ekim 2011, 145-155, Kahramanmaraş.

Özkan, K., 2004. Prof. Dr. Bekir Sitkı EVCIMEN Sedir Koruma Ormanında Toros Sedir'inin (Cedrus libani A. Rich.) Gelișimi ile Yetișme Ortamı Faktörleri Arasındaki İlişkiler. Anadolu Üniversitesi Bilim ve Teknoloji Dergisi, 5 (2): 327-331.

Özkan, K., Gülsoy, S., Mert, A., 2008. Interrelations Between Height Growth and Site Characteristics of Pinus nigra Arn. ssp. pallasiana (Lamb.) Holmboe. J. The Malaysian Forester, 71, 9-16.

Özkan, K., Kuzugüdenli, E. 2010. Akdeniz Bölgesi Sütçüler Yöresinde Kızılçamın (Pinus brutia ten.) Verimliliği ile Yetişme Ortamı Özellikleri Arasındaki İlişkiler. Turkish Journal of Forestry, 1(1), 16-29.

Özkan, K., 2013. Modeling productivity of Crimean pine by using fuzzy logic applications. Eurasian Journal of Forest Science, 1(1), 51-59.

Saatçioğlu, F., Pamay, B., 1962. Adana Bölgesinin Kalkınmasında Kızılçamın (Pinus brutia ten.) Önemi ve Silvikültürü. İstanbul Ünivertsitesi. Orman Fakültesi Dergisi, Seri A, Cilt XII, Sayı: 2:88101.

Sağıroğlu, M., Dalgiccedil, S., Toksoy, S., 2013. Medicinal Plants Used in Dalaman (Muğla), Turkey. Journal of Medicinal Plants Research, 7(28), 20532066.

Şen, Z., 2009. Bulanık Mantık İlkeleri ve Modelleme, Genişletilmiş 3. Baskı, Su Vakfı Yayınları.

Tetik, M., Yeşilkaya, Y., 1997. Antalya Yöresi Doğal Kızılçam Ormanlarında Anakaya-Toprak DerinliğiBonitet Ilișkileri. Batı Akdeniz Ormancılık Araştırma Müdürlüğü, Teknik Bülten No: 6, Antalya, $41 \mathrm{~s}$.

Zadeh, L. A., 1965. Fuzzy Sets, Information \& Control, Vol. 8, S. 185-195.

Zech, W., Çepel, N., 1972. Güney Anadolu'daki Bazı Kızılçam Meşcerelerinin Gelişimi ile Toprak ve Reliyef Özellikleri Arasındaki İlişkiler. İstanbul Üniversitesi, Orman Fakültesi Yayın No:191. 